\title{
ANALISIS KETERLAKSANAAN PROGRAM PERKULIAHAN MICRO TEACHING BERBASIS LESSON STUDY DI PROGRAM STUDI PENDIDIKAN SEJARAH FKIP UM METRO
}

\author{
Bobi Hidayat, S.Pd., M.Pd. \\ Pendidikan Sejarah FKIP Universitas Muhammadiyah Metro \\ Email: hidayatbobi1234@gmail.com
}

\begin{abstract}
Abstrak
Perkuliahan Micro Teaching di Program Studi Pendidikan Sejarah mengintegrasikan kegiatan lesson study. Hal ini dimaksudkan agar perkuliahan menjadi lebih baik dikarenakan dapat memberdayakan seluruh mahasiswa praktikan dan pembelajaran dapat lebih terbuka sehingga masukan untuk perbaikan dapat diberikan. Melihat pentingnya evaluasi yang sifatnya menyeluruh dan selama ini belum dilakukan dan sampai dituliskan hasil dari analisisnya, maka diperlukan analisis secara menyeluruh terkait dengan pelaksanaan perkuliahan micro teaching berbasis lesson study.

Penelitian ini merupakan penelitian kualitatif dengan menggunakan pendekatan deskriptif kualitatif. Data dikumpulkan menggunakan teknik dokumentasi, angket atau kuesioner dan wawancara.

Hasil penelitian menunjukkan bahwa dari indikator yang diukur, menunjukkan kategori yang baik dan sangat baik. Indikator yang diukur antara lain 1). Waktu dan Tempat perkuliahan Micro teaching dengan kategori baik, 2). Membekalkan mahasiswa calon guru dengan kategori sangat baik, 3). Pelaksanaan Lesson study dengan kategori sangat baik, 4). Kinerja Dosen dalam pembelajaran dengan kategori sangat baik, dan 5). Evaluasi yang dilakukan dengan kategori sangat baik.
\end{abstract}

Keywords: Micro teaching dan Lesson study

\begin{abstract}
Micro teaching lesson in historical education program integrates lesson study activity. It's done in order to make the lesson be better because all of apprentice students are worked and the improvement suggestions can be given toward the lesson. Since there was no comprehensive evaluation and its analysis done before, it's very important to do such kind of evaluation in the lesson.

This research was qualitative research with qualitative descriptive approach. The data was gathered by documentation, quesionaire and interview technique.

The research result showed that the measured indicators tended to be good and very good categorized. The indicators measured were 1) the micro teaching lesson's time and place in good categorized, 2)the apprentice students supplying in very good categorized, 3) the lesson study implemetation in very good categorized, 4) the lecture's lecturing in very good categorized, and 5) the evaluation done in very good categorized.

Keywords: Micro teaching and Lesson study
\end{abstract}

\section{PENDAHULUAN}

Guru adalah pendidik professional dengan tugas utama mendidik, mengajar, membimbing, mengarahkan, melatih, menilai, dan mengevaluasi peserta didik pada pendidikan anak usia dini jalur pendidikan formal, pendidikan dasar, dan pendidikan menengah (UU RI tentang Guru dan Dosen No 14 tahun 2005). Pembentukan guru yang professional memerlukan waktu yang cukup lama. Semua aspek dan komponen ikut berperan dalam membentuk guru yang professional. Manurut Karwono dan Heni Mularsih (2012:3) pembentukan kemampuan profesionalisme keguruan memerlukan 
pengintegrasian fungsional antara teori, praktik dan materi serta metodologi penyampaianya. Hal ini akan diperoleh mulai pada saat calon guru menempuh pendidikan di perguruan tinggi sampai guru itu terjun langsung di sekolah dan mengikuti dengan baik wahana untuk mengembangkan keterampilan guru dalam rangka membentuk guru yang professional.

Salah satu intitusi yang sangat berperan dalam membentuk guru yang professional adalah LPTK. Didalam LPTK calon guru dididik, dibekali dan dilatih dengan berbagai macam keterampilan mengajar yang harapanya setelah lulus akan mampu mengimplementasikan ilmunya saat berada di sekolah.

Hal ini yang dilakukan oleh Program Studi Pendidikan Sejarah FKIP UM Metro. Salah satu proses yang perlu dilakukan guna membekali mahasiswa adalah dengan menyelenggarakan perkuliahan yang komprehensif termasuk didalamnya ada pembekalan terhadap mahasiswa calon guru tentang kependidikan dan pengajaran di sekolah. Salah satu pembekalan yang dilakukan adalah dengan memberikan praktik mengajar pada sekala kecil dengan teman sebaya sebagai siswanya yang biasa disebut dengan pembelajaran micro teaching.

Pembelajaran mikro (micro teaching) adalah salah satu pendekatan atau cara untuk melatih penampilan mengajar yang dilakukan secara "micro" atau disederhanakan (Sukirman, 2012:21). Pembelajaran mikro juga diartikan sebuah model pengajaran yang dikecilkan atau disebut juga dengan real teaching (Asril, 2012:43). Pembelajaran mikro dilaksanakan tidak hanya pada guru namun juga dilaksanakan pada mahasiswa calon guru sebagai wahana untuk belajar dan mengembangkan diri dibidang pembelajaran.

Pelaksanaan pembelajaran micro teaching yang dilaksanakan pada Program Studi Pendidikan Sejarah dilaksanakan dengan mengintegrasikan program lesson study dimana mahasiswa dilatih untuk merencakan proses pembelajaran dengan teman sejawat mengikuti langkah-langkah pembelajaran lesson study yaitu plan, do dan see. Menurut Hendayana, (2007:10) lesson study merupakan model pembinaan profesi pendidik melalui pengkajian pembelajaran secara kolaboratif dan berkelanjutan berlandaskan prinsip-prinsip kolegalitas dan mutual learning untuk membangun komunitas belajar. Lesson study bukan merupakan metode atau strategi pembelajaran akan tetapi merupakan suatu kegiatan.

Menurut Susilo (2011:35) siklus pengkajian pembelajaran Lesson study di Indonesia meliputi 3 tahap: tahap Perencanaan (Plan), tahap pelaksanaan (Do), tahap pengamatan dan refleksi (See). Siklus pengkajian pembelajaran 
dilaksanakan dalam tiga tahap, seperti dalam Gambar berikut ini.

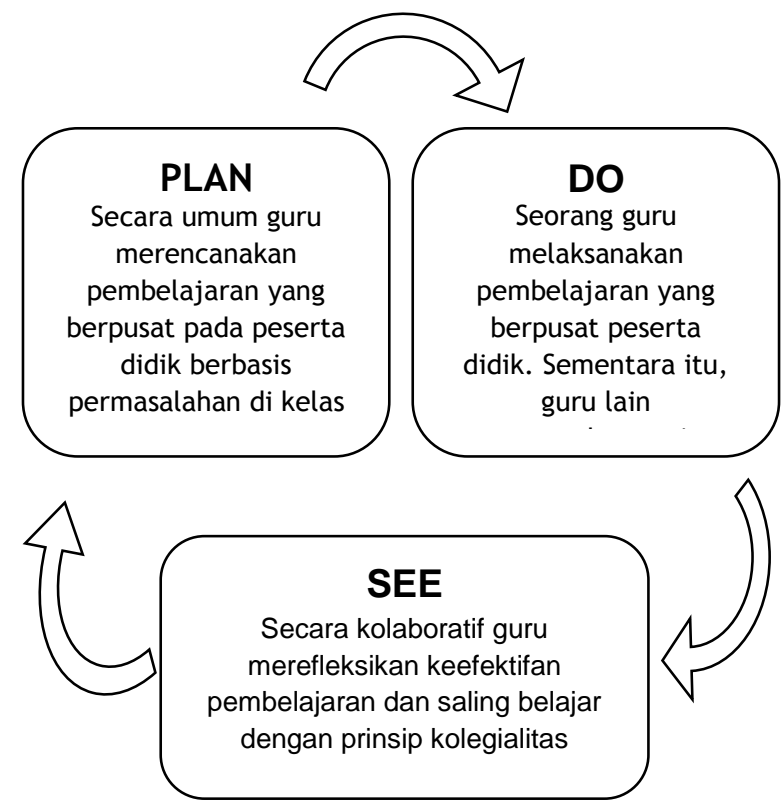

Siklus Pengkajian Pembelajaran dalam Lesson Study di Indonesia Sumber: Susilo, 2011

Berbagai upaya telah dilakukan guna mengembangkan kemampuan mengajar mahasiswa. Namun belum dilakukan evaluasi secara menyeluruh dan hasilnya dapat dijadikan acuan tindakan penyelenggara perkuliahan. Sehingga penelitian ini akan memaparkan hasil analisis keterlaksanaan perkuliahan micro teaching berbasis lesson study secara menyeluruh, mulai dari waktu pelaksanaan, kinerja dosen pengampu sampai evaluasi pembelajaran yang dilakukan.

\section{METODE PENELITIAN}

Penelitian ini merupakan penelitian kualitatif dengan menggunakan pendekatan deskriptif kualitatif.
Penelitian ini dilakukan pada mahasiswa program studi pendidikan sejarah yang mengambil mata kuliah micro teaching. Data dikumpulkan menggunakan teknik dokumentasi, angket atau kuesioner dan wawancara.

Instrumen yang mendasar dalam penelitian adalah angket atau kuesioner. Angket atau kuesioner sebelum digunakan untuk malukukan penelitian akan diuji terlebih dahulu validitas dan reabilitasnya. Uji validitas dan reabilitasnya dilakukan pada mahasiswa Program Studi Pendidikan Fisika yang mengambil mata kuliah micro teaching sebanyak 21 mahasiswa. Kemudian hasil uji coba dianalisis menggunakan program SPSS versi 19. Hasil analisis uji coba menunjukkan bahwa ada dua item angket dari 20 item angket yang tidak valid. Berdasarkan beberapa pertimbangan, maka peneliti memutuskan untuk merevisi angket menjadi 18 item angket yang kemudian digunakan untuk melakukan penelitian. Angket yang digunakan ada 7 item pernyataan yang termasuk pernyataan tentang kepuasan pengguna terkait dengan pelayanan laboratorium micro teaching dan ada 11 item pertanyaan yang digunakan untuk mengukur keterlaksanaan perkuliahan micro teaching. Sehingga hanya 11 item pernyataan yang digunakan untuk membahas dalam artikel ini.

HASIL DAN PEMBAHASAN 
Pembelajaran micro teaching merupakan pembelajaran yang berbasis pada praktik mengajar mahasiswa. Berdasarkan hasil analisis dari angket yang digunakan, ditambah dengan hasil wawancara dapat menggambarkan keterlaksanaanya perkuliahan micro teaching di Program Studi Pendidikan Sejarah.

Setelah dilakukan penelitian menggunakan angket atau kuesioner didukung dengan hasil wawancara menunjukkan bahwa pelaksanaan perkuliahan micro teaching berbasis lesson studi dapat dikategorikan baik dan sangat baik. Hasil penelitian ini dapat dilihat pada tabel berikut ini:

Tabel :Sebaran Hasil Penelitian berdasarkan variabel, indikator dan kategori instrument penelitian

\begin{tabular}{|l|l|l|}
\hline $\begin{array}{c}\text { Variabel } \\
\text { Penelitian }\end{array}$ & \multicolumn{1}{|c|}{$\begin{array}{l}\text { Indikator } \\
\text { Penelitian }\end{array}$} & Kategori \\
\hline \multirow{4}{*}{$\begin{array}{l}\text { Waktu dan } \\
\text { Pempat } \\
\text { Pegram } \\
\text { Micro } \\
\text { perkuliahan } \\
\text { teaching } \\
\text { Micro } \\
\text { teaching }\end{array}$} & Baik \\
\cline { 2 - 3 } & $\begin{array}{l}\text { Membekalkan } \\
\text { mahasiswa } \\
\text { calon guru }\end{array}$ & Sangat \\
\cline { 2 - 3 } & $\begin{array}{l}\text { Pelaksanaan } \\
\text { Lesson study }\end{array}$ & $\begin{array}{l}\text { Sangat } \\
\text { Baik }\end{array}$ \\
\cline { 2 - 3 } & $\begin{array}{l}\text { Kinerja Dosen } \\
\text { dalam } \\
\text { pembelajaran }\end{array}$ & $\begin{array}{l}\text { Sangat } \\
\text { Baik }\end{array}$ \\
\cline { 2 - 3 } & $\begin{array}{l}\text { Evaluasi yang } \\
\text { dilakukan }\end{array}$ & $\begin{array}{l}\text { Sangat } \\
\text { Baik }\end{array}$ \\
\hline
\end{tabular}

Sumber: Hasil Analisis Data Penelitian
Hasil penelitian berdasarkan tabel di atas, juga ditunjang dengan adanya wawancara sebegai jalan untuk menguatkan hasil angket penelitian. Hasil wawancara juga menunjukkan adanya penilaian yang positif dari mahasiswa terkait dengan pelaksanaan perkuliahan micro teaching berbasis lesson study di Program Studi Pendidikan Sejarah.

Hasil temuan penelitian menunjukkan bahwa pelaksanaan perkuliahan micro teaching berbasis lesson studi dapat dikategorikan baik dan sangat baik. Berdasarkan hasil penelitian waktu pelaksanaan perkuliahan dinyatakan baik yaitu dilakukan mulai pukul 08.00-11.40 wib. Sedangkan tempat yang digunakan adalah ruang kelas dan tempat praktik mengajar di laboratorium micro teaching juga sudah cukup memadai.

Perkuliahan micro teaching yang dilakukan juga sudah dapat memberikan bekal pada mahasiswa calon guru dengan melakukan praktik mengajar untuk beberapa kali. Selain praktik mengajar atau memberikan kemampuan pedagogik, perkuliahan juga sudah dapat memberikan bekal pada mahasiswa calon guru untuk menguasai perangkat pembelajaran, yaitu dengan memberikan pemahaman sekaligus memberikan kesempatan pada mahasiswa calon guru untuk praktik membuat perangkat pembelajaran dan 
kelengkapan pembelajaran lainya. Sehingga mahasiswa seperti sudah menjadi guru yang sesungguhnya.

Perkuliahan micro teaching juga dintegrasikan dengan model pembelajaran lesson study. Hal ini dilakukan dengan tujuan agar mahasiswa dapat belajar mengajar secara terbuka dan dapat saling memberikan masukan satu dengan yang lainya sebagai bentuk perbaikan. Setelah dilakukan penelitian, pelaksanaan lesson study pada perkuliahan micro teaching berjalan dengan sangat baik. Mahasiswa dapat berbagi satu dengan yang lainya. Setiap mahasiswa yang akan praktik mengajar, akan berkoordinasi dengan mahasiswa yang lain dan dosen pengampu mulai dari perencanaan, pelaksanaan sampai dengan refleksi yang akan dilakukan. Hal ini juga diperkuat dengan hasil temuan penelitian Tjipto Subadi (Jurnal Varia Pendidikan, Vol. 21, No. 2, Desember 2009) yang menunjukkan bahwa, upaya peningkatan keterampilan mengajar mahasiswa dapat dilakukan melalui pembelajaran micro teaching yang diintegrasikan dengan kegiatan lesson study. Pelaksanaannya menggunakan siklus, artinya peningkatan keterampilan mengajar dapat dilakukan dengan cara berulangulang sampai beberapa siklus dalam pembelajaran.
Selain proses pembelajaran yang berkaitan dengan mahasiswa, kinerja dosen juga dilakukan analisis keterlaksanaanya. Berdasarkan hasil penelitian, dosen pengampu mata kuliah sudah memenuhi tugasnya dengan sangat baik dalam membimbing mahasiswa pada perkuliahan micro teaching. Dosen pengampu mata kuliah menyampaikan tujuan pembelajaran, dosen pengampu juga memberikan teladan yang baik serta dapat mengarahkan mahasiswa untuk belajar melatih diri dalam mengembangkan kemampuan mengajarnya.

Analisis selanjutnya yang dilakukan dalam penelitian ini adalah tahap akhir, yaitu tahap evaluasi. Evaluasi yang dilaksanakan pada perkuliahan micro teaching berbasis lesson study menyeluruh mulai dari penilaian produk dari perangkat pembelajaran, penilaian kinerja mahasiswa dalam proses pembelajaran, penilaian terhadap pelaksanaan lesson study sampai penilaian teman sejawat. Evaluasi dilakukan secara menyeluruh dengan tujuan agar dapat mengukur kemampuan mahasiswa secara menyeluruh dan dapat mendeteksi kelemahan dari mahasiswa sehingga dapat dijadikan evaluasi untuk perbaikan. Berdasarkan hasil penelitian evaluasi yang dilakukan berjalan sangat baik. Evaluasi dapat mengetahui sejauh mana kemampuan mahasiswa dalam 
menguasai teknik dalam melaksanakan pembelajaran.

\section{PENUTUP}

\section{Simpulan}

Simpulan yang dapat diambil dari hasil penelitian ini adalah pelaksanaan perkuliahan micro teaching berbasis lesson study di Program Studi Pendidikan Sejarah FKIP UM Metro berjalan dengan baik. Hal ini diperoleh dari hasil penelitian yang meliputi waktu dan tempat penelitian, kinerja dosen, sampai dengan evaluasi yang dilakukan. Kesimpulan juga ditunjang dengan data hasil wawancara dan dokumentasi yang diperoleh juga menunjukkan hasil yang baik

\section{Saran}

Berdasarkan hasil penelitian yang menunjukkan bahwa hasil yang diperoleh dapat dikatakan sangat baik, akan tetapi masih perlu untuk ditingkatkan dan perlu adanya inovasi dalam pembelajaran yang lain. Inovasi dalam pembelajaran dapat diintegrasikan atau ditambahkan dalam proses pembelajaran sebagai jalan untuk menambah dan mengembangkan wawasan pembelajaran pada mahasiswa.

\section{DAFTAR PUSTAKA}

Asril, Zainal. 2012. Micro Teaching Disertai dengan Pedoman
Pengalaman Lapangan. Jakarta. PT Raja Grafindo Persada

Hendayana, dkk. 2007. Lesson Study Suatu Strategi Untuk Meningkatakan Keprofesionalan Pendidik (Pengalaman IMSTEPJICA). Bandung: UPI Press

Karwono dan Heni Mularsih. 2012. Belajar dan Pembelajaran serta Pemanfaatan Sumber Belajar (edisi revisi). Jakarta. PT Raja Grafindo Persada

Sukirman, Dadang. 2012. Pembelajaran Micro Teaching. Jakarta:Direktorat Jendral Pendidikan Islam Kementerian Agama

Susilo, $H$, Chotimah, $H$, Joharmawan, $R$, Jumiati, Dwita sari, Y, dan Sunarjo. 2011. Lesson Study Berbasis Sekolah. Malang: Bayumedia Publising

Tim Penyusun.2006. Himpunan Peraturan Perundang-undangan tentang Guru dan Dosen.Bandung.Fokusmedia

Tjipto Subadi. "Peningkatan Kualitas Pembelajaran Micro Teaching dan PPL (Program Pengalaman Lapangan) melalui Lesson Study bagi Calon Guru". Varia Pendidikan.Volume 21 No. 2, Desember 2009. Publikasi Ilmiah UMS 